\title{
Should We Play Games Where Energy Is Concerned? Perceptions of Serious Gaming as a Technology to Motivate Energy Behaviour Change among Social Housing Residents
}

\author{
Christine Boomsma ${ }^{1, *}$, Rebecca Hafner ${ }^{2}$ (D), Sabine Pahl ${ }^{3}$, Rory V. Jones ${ }^{2}$ and Alba Fuertes ${ }^{2}$ \\ 1 Social and Organisational Psychology Department, Leiden University, P.O. Box 9555, \\ 2300RB Leiden, The Netherlands \\ 2 Department of Architecture and Built Environment, Plymouth University, Drake Circus, \\ Plymouth PL4 8AA, UK; rebecca.hafner@plymouth.ac.uk (R.H.); rory.jones@plymouth.ac.uk (R.V.J.); \\ alba.fuertes@plymouth.ac.uk (A.F.) \\ 3 School of Psychology, Plymouth University, Drake Circus, Plymouth PL4 8AA, UK; \\ sabine.pahl@plymouth.ac.uk \\ * Correspondence: c.boomsma@fsw.leidenuniv.nl
}

Received: 25 April 2018; Accepted: 23 May 2018; Published: 25 May 2018

\begin{abstract}
The invisibility and intangibility of energy are key challenges faced by communicators looking to reduce household energy demand. 'Serious games' - defined as formalized, goal-oriented games designed to educate, or promote health and well-being-are one potential strategy that may help to alleviate these challenges. This paper discusses the suitability of serious gaming as an educational and behavioural change tool within the context of social housing-a faction often overlooked when it comes to household energy research. The paper takes a two-part approach. First, we review current literature on serious energy games, and second, we discuss perceptions of serious energy games amongst social housing residents using data from two surveys (Survey A, $n=536$; Survey $\mathrm{B}, n=78$ ). Perceptions of serious energy games were found to be mixed. Some residents liked the idea of a game for energy, particularly if clear, actionable solutions for reducing energy bills were provided. However, others were disinterested, due to existing time pressures, negative perceptions of gaming, and limited confidence using computers or tablets. As such, uptake may be met with challenges. The findings highlight the need for interdisciplinary collaborations and user-led approaches for the design of successful and engaging serious energy games.
\end{abstract}

Keywords: serious gaming; household energy use; social housing; public perceptions

\section{Introduction}

There are many challenges when it comes to communicating about energy use and saving. Energy is invisible, and thus is often difficult for householders to accurately conceptualise. There is a lack of feedback on everyday energy consumption, often limited to monthly, or even yearly, energy bills that only show an overall amount and leave householders guessing how, when, or through which behaviours energy was used [1]. Indeed, Burgess and Nye argued that energy is "doubly invisible" [2] (p. 4454), due to the fact that the impact and amount of energy use are largely abstract concepts, and it is often difficult to link these values to daily energy-using activities. This invisibility leads to common misperceptions around energy use, such as those reported by Attari et al. [3] whereby people tend to underestimate the energy use and savings associated with efficiency behaviours (such as insulating their home, or installing efficient equipment), and overestimate the energy savings associated with 
curtailment behaviours (such as turning off lights). Also, because the qualities of energy cannot be directly perceived, there is often a lack of emotional involvement with energy use [1]. Determining how we can increase the visibility of energy use in order to effectively engage householders with energy conservation and reduce energy consumption has subsequently become the topic of much research interest in recent years. The use of (visual) feedback has come up as one of the main solutions to overcoming these barriers to communication in the field of household energy use. Visual information allows householders to engage with energy use more directly, enabling them to see what is normally invisible [4,5]. Furthermore, providing energy feedback in the form of a visual real-time representation of consumption levels can help bring the long-term consequences of energy use (e.g., fuel costs) to the shorter term [6]. The drive for the widespread 'rollout' of smart energy monitoring systems (SEMs) is one response to this call [1,7-10]. However, despite its potential, the effects of smart meter feedback on reducing energy demand have been questioned [11]. In particular, it is unclear whether feedback displays can hold householders' interest in the longer term as the novelty wears off $[12,13]$. Other visual feedback techniques have been proposed, such as the use of infrared images to visualise heat loss in the home [4,5], and devices that visualise energy use through art-inspired design (e.g., the power-aware cord [14]). However, these techniques can be expensive and may be difficult to up-scale in order to roll out to a large population [4]. As such, alongside feedback displays and other techniques, there remains a need for the development of easy-to-scale educational tools that can link the abstract concept of energy to specific daily energy-using behaviours, and that can offer an interactive, evolving way to engage with energy consumption over a longer time period. Given the growing evidence that some people respond better to 'playful' forms of information and feedback [15], 'gamification' or the development of 'serious games' to educate about energy practices is one potential avenue that may provide an answer to this call.

This paper will take a two-part approach; in the first part, the current literature on serious gaming within the context of household energy use will be reviewed. In the second part of the paper, a case study is presented; this case study provides an example of how insights from social and behavioural research can inform technical design. Rather than conducting social science research at the end of technological development (e.g., through evaluating use of a serious game), the current research was done before game development. Specifically, the case study presented here allows us to study the perceptions of serious games on energy use among residents in a specific sector, namely, social housing. Findings will be discussed from two housing surveys, looking at, amongst others, interest in-and motivations for-playing serious games amongst this group of householders. Social housing, or affordable housing, provides housing with subsidised rent for people on low incomes. This sector of housing is often overlooked when it comes to research on household energy use [16,17]. However, at the same time, developing effective methods to communicate with residents about energy use is particularly important in this sector. Many social housing associations and local authorities attempt to engage their social housing tenants with energy efficiency. In these campaigns the focus may not be on increasing energy savings per se, but on using energy efficiently to ensure comfort, health, well-being, and affordability (e.g., [18]). The social housing sector houses more vulnerable groups than any other housing sector [19]. In England, 72\% of households living in social housing have an income in the two lowest income quintiles, so financial pressures in these households are high $[19,20]$. As a consequence, social housing residents will be one of the hardest affected by future fluctuations and increases in fuel prices as we transition to a low-carbon energy system. Already, low-income households are 2.5 times more likely to struggle keeping their home adequately warm, compared with the general population (in Europe, [21]), due to a combination of factors including low household income, high energy costs, and poor energy efficiency of the house [22]. Cold homes, in turn, have been associated with a range of negative health outcomes (cf. [23-25]). Reductions in, and more efficient use of, energy through energy efficiency improvements and behaviour change could provide an opportunity to reduce financial concerns and improve housing conditions in the social housing sector [26-29]. Serious games on energy use may offer a novel way to help social housing residents manage their energy use. The next 
section will review current research on serious gaming and its potential to engage households with energy conservation.

\section{Serious Games as a Tool to Raise Awareness and Change Behaviour}

In the late 1990s, Fogg and colleagues pioneered research into persuasive technologies, conceptualised as "interactive computing systems designed to change people's attitudes or behaviour" [30] (p. 1). Since then, developments in the field of 'serious gaming' have gained substantial momentum. 'Serious games' are formalized, goal-oriented games which are designed to go "beyond the role of entertainment" [31], and instead aim to educate, or to promote health and well-being [32]. Serious games are physical games which can be digital or material (i.e., nondigital) and are intended to be played by users; this is not to be confused with the Game Theory Model which refers to the study of mathematical models and has also been applied to the household energy domain (cf. [33]).

With regards to serious games, according to Hamari, Koivisto, and Sarsa [34], gamification can be conceptualised as having three constituent parts: (1) initial motivational affordances or goals, (2) resulting psychological outcomes that are akin to those experienced in 'regular' gaming, and (3) behavioural outcomes, in terms of the establishment of new, desired behaviour patterns and habits within and outside the game context. Most serious games use some variation of the points-badges-leaderboards model of 'four-square' [34]. 'Four-square' has been described as the arguable blueprint of the gamification movement [32], incorporating a series of game-like elements to encourage interaction and shared engagement, including 'points' for participation, 'badges' for unlocking achievements, 'leaderboards' which allow for comparison with members of one's social group, and 'rewards' as incentives paired with goals and achievements. By incorporating a variety of these gamelike elements, serious games are able to encourage continued interest and interaction, enabling establishment of new behaviour patterns over time, which are then further reinforced through social comparison on leaderboards or associated social media platforms.

One of the most well-publicized examples within the environmental domain is 'Chromaroma' -a gaming platform that allows users to track their movements across London using their public transport card, using timestamped swipes in and out of underground stations. The game encourages users towards more sustainable behaviour patterns with goals that place walking, cycling, and use of public transport over car driving, awarding points for unlocking achievements, and encouraging competition through leaderboards. The game provides an example of the move away from people escaping into a virtual world of games, and instead towards a future which finds games escaping into everyday life [32]. Serious games are at the forefront of this movement, allowing the user to find refreshed interest and enjoyment in commonplace everyday tasks and activities that they habitually engage in. Crucially by re-engaging users with real-life tasks and activities, gamification has the potential to overcome 'action inertia' - one of the main barriers to behaviour change commonly identified in the social science and environmental literatures [35]. Serious games have been shown to be effective in changing behaviour in a wide variety of contexts, including sustainability and energy conservation, health and well-being, commerce, and education. The next sections will discuss examples of serious games in the health and energy conservation fields. The former is relevant here as the focus of this paper is on implementing a serious game in the social housing sector. As mentioned in the introduction, communication about energy use in this sector is not only concerned with energy conservation, but also with finding the right balance between conserving energy and having a healthy home environment.

Within the health context, gamification has focused on engaging users to take responsibility for their own health, either by targeting self-improvement, for example in fitness, healthy eating, or cognitive abilities, or by targeting more effective self-management of health challenges and chronic conditions, such as diabetes or asthma (see [36]). It is suggested that framing health challenges as a game helps to encourage engagement with these challenges as it can make failure less daunting, and can break targets down into more psychologically manageable objectives, meaning that people perceive better odds of eventually succeeding [37]. In their meta-analytic review of serious games 
for health, DeSmet et al. [38] found that the average effect size for behaviour change was positive but small, indicating overall improvement in the adoption of healthy lifestyle practices as a result of engagement. Games that, in addition to providing information, offer an environment which allows users to autonomously seek information on positive behaviour change strategies are particularly effective. The provision of such an environment is vital in enabling behaviour change as it evokes feelings of competency and control which are essential in motivating choice $[39,40]$. Furthermore, given that affective responses are a prominent driver of behaviour in nearly all aspects of decision-making behaviour (see, for example, [41]), creating an emotional involvement in the game or storyline is often an effective strategy for encouraging continued involvement, and for promoting behaviour change in desired directions. Games for health have subsequently been shown to have substantial potential for guiding behaviour in desired directions, and can also help to overcome the challenge of encouraging those who are not overtly concerned about their health to engage with health-promoting behaviours (see, [42]).

Returning to the environmental domain and energy consumption, use of gaming to promote "good, green choices" has seen a surge of research interest in recent years [43]. Motivational techniques associated with gaming are often included in studies aimed at influencing pro-environmental behaviour, including social comparison [10,44], goal setting [45], feedback [46,47], and rewards and incentives [48]. Serious games within the environmental domain fuse a variety of these principles and techniques with the concepts of playful interaction and gameful design in order to create stimulating learning environments that can be used to educate and motivate lasting behaviour change [49]. Although several examples of serious games designed to educate users about energy consumption and motivate energy-saving behaviours exist (e.g., [50-58]), empirical research into the effectiveness and use of these games in different housing contexts is limited [51]. Some studies have suggested that serious games can increase awareness of energy consumption practices in the short term. Two such examples are the games 'EnergyLife' and 'EcoIsland'. In 'EnergyLife' [53], users are provided with real-time feedback information based on wireless power sensor data linked to appliances in their own home, as well as tips and quizzes to educate on how to best conserve energy. Gamers are also able to compare their performance with others in the 'in-game' community using leaderboards. In 'EcoIsland' [54], users strive to save a virtual island from loss of land through rising sea levels, by reducing the amount of emissions that each household emits. Users play as one household on the virtual island, and have to self-report steps they have taken to change their emissions levels. However, research on both of these games lacked the inclusion of a control group, which makes it difficult to fully assess the results reported (see also [50]).

More in-depth research was done on three other serious games: 'Energy Chickens', 'Power House', and 'Green my Place'. The first of these, 'Energy Chickens' [56], runs on actual consumption data and it was designed to encourage energy savings in an office environment, with the overall goal of maintaining the health of a virtual pet chicken. The game incorporated elements of goals, feedback, and social comparison, and was found to be successful in increasing energy awareness and decreasing energy use in office environments (versus a no-game control), with persistence of the effects over a 12-week trial period. Similarly, the game 'Power House' [57] used the virtual world of a typical family home to teach users about energy savings. The game incorporated real-time feedback data on consumption levels from utility companies which was presented to users on their personalised 'dashboard'. Users received credits for reducing their energy use, and could compete with family and friends on social leaderboards. A laboratory trial showed that playing the game for $30 \mathrm{~min}$ resulted in significantly increased likelihood of engagement in efficiency behaviours, such as turning off lights when leaving the room, in contrast to a control group who played a similar but thematically different entertainment game. Similarly, a field test using smart meter data revealed a significant $(2 \%)$ decrease in electricity usage for the 30-day period following 'Power House' play versus a control [57]. Finally, in the game 'Green my Place' [58], users aimed to increase the efficiency of their virtual building via use of educational tools and engagement in eco-action mini games. Teams competed to unlock achievements 
and win awards that could improve the virtual representation of their team building, with players' individual scores reflected alongside that of their team or building on in-game leaderboards. The game was found to be effective in encouraging energy use conservation over a three-month period, in comparison to a no-game control.

In summary, there seems to be potential for serious games to encourage energy-saving behaviour and raise awareness on energy consumption practices. However, studies are limited and there are many questions still to explore. One question concerns the role of serious energy games in different housing contexts, especially those where householders may have, or perceive, limited agency as to what they can do to save energy [51]. Also, the majority of studies focus on the effects of serious energy games on energy-saving behaviour once the game is in place. While this research is important in establishing the usefulness of serious games to reduce household energy demand, we posit that it is also important to look more closely into how serious games are developed for the user. Specifically, it is important to address the issue of (lack of) interest/engagement in energy conservation that is commonplace in the energy communication field. Getting households to engage with energy consumption messages/communications has been acknowledged as one of the largest obstacles to the success of these initiatives $[4,11]$. Serious energy games are positioned in the literature as a 'fun' and 'interactive' way to engage with energy in order to overcome this obstacle, but, so far, research into users' interest in and motivations to play serious energy games is limited. So, in the remainder of this paper, a case study on the development of a serious energy game in the social housing context is discussed. Quantitative and qualitative survey data is used to study the perceptions of a serious energy game among social housing residents by answering the following explorative research questions:

(1) Which characteristics do social housing residents look for in a serious energy game?

(2) Which factors are related to interest in playing a serious energy game among social housing residents?

(3) What is the role of access, experience, and confidence with digital media in the potential uptake of a serious energy game in the social housing context?

\section{Developing a Serious Energy Game for Social Housing Residents: A Case Study}

The EnerGAware (Energy Game for Awareness of energy efficiency in social housing communities) research project aims to develop and test a serious energy game in a field study among social housing residents. The EU Horizon 2020 funded project is a collaboration between game developers, building engineers, psychologists, energy providers, IT engineers, and a social housing provider (for more information, see energaware.eu). During the game development phase of the project, two surveys were administered to capture responses from social housing residents in a city in South West England. Both surveys were conducted at the start of the field study before any intervention took place. The full surveys included measures on energy-related issues in the home, perceptions and behaviours related to energy use at home, use of digital devices and social networks, and demographics and household characteristics. Data from these larger surveys is used in the current paper to discuss perceptions of a serious energy game in this sample of social housing residents.

\subsection{The Social Housing Surveys}

\subsubsection{Survey A}

A self-report, paper-based survey, accompanied by a letter, a one-page flyer about the project, and a prepaid return envelope was sent by post to 2772 households in May 2015. The letter invited households to either complete the paper-based survey and return it in the prepaid returning envelope or undertake the survey online. A prize draw (for family days out and shopping vouchers) was used as an incentive to encourage households to complete and return the survey. After two weeks, a further letter was sent out to remind households to complete the survey. 
The survey included measures on access, experience, and confidence with digital media-asking respondents to report on their access to the internet, their experience with (digital) games, and their confidence with using a computer and the internet. An open-ended question was also included asking respondents to describe what a game on energy saving should include to make them want to play it; for the full list of items, see Appendix A. In total, 536 (503 paper-based and 33 online) of the households completed the survey, giving an overall response rate of 19.3\%. A number of items included 'don't know' or 'not applicable' response options. In addition, some respondents did not provide answers to all the items in the survey. As a result, the number of valid cases for each analysis varies. Unless stated otherwise, missing, 'don't know' and 'not applicable' responses were excluded from the analysis. Table 1 provides an overview of the demographics.

Table 1. Demographic variables.

\begin{tabular}{|c|c|c|c|c|}
\hline \multirow[t]{2}{*}{ Demographic Variable } & \multicolumn{2}{|c|}{$\begin{array}{l}\text { Survey A: Mean and/or } \\
\text { Frequency }\end{array}$} & \multicolumn{2}{|c|}{$\begin{array}{l}\text { Survey B: Mean and/or } \\
\text { Frequency * }\end{array}$} \\
\hline & $18-24$ & $2 \%$ & $18-24$ & $0 \%$ \\
\hline \multirow{8}{*}{ Age } & $25-34$ & $9 \%$ & $25-34$ & $12 \%$ \\
\hline & $35-44$ & $12 \%$ & $35-44$ & $17 \%$ \\
\hline & $45-54$ & $17 \%$ & $45-54$ & $23 \%$ \\
\hline & $55-64$ & $18 \%$ & $55-64$ & $17 \%$ \\
\hline & $65-74$ & $18 \%$ & $65-74$ & $23 \%$ \\
\hline & $75+$ & $16 \%$ & $75+$ & $8 \%$ \\
\hline & Missing & $10 \%$ & Missing & $1 \%$ \\
\hline & \multicolumn{2}{|c|}{$\begin{array}{c}M=58(S D=17.27), \text { ranging } \\
\text { between } 18 \text { and } 96\end{array}$} & \multicolumn{2}{|c|}{$\begin{aligned} M= & 54(S D=15.33), \text { ranging } \\
& \text { between } 26 \text { and } 84\end{aligned}$} \\
\hline \multirow{3}{*}{ Gender } & Male & $37 \%$ & Male & $47 \%$ \\
\hline & Female & $56 \%$ & Female & $51 \%$ \\
\hline & Missing & $7 \%$ & Missing & $1 \%$ \\
\hline \multirow{6}{*}{ Employment status } & Retired & $38 \%$ & Retired & $35 \%$ \\
\hline & Employed & $32 \%$ & Employed & $36 \%$ \\
\hline & Unemployed & $9 \%$ & Unemployed & $6 \%$ \\
\hline & Seeking work & $3 \%$ & Seeking work & $3 \%$ \\
\hline & Student & $1 \%$ & Student & $4 \%$ \\
\hline & Missing & $19 \%$ & Missing & $17 \%$ \\
\hline \multirow{3}{*}{$\begin{array}{l}\text { Welfare benefits (e.g., } \\
\text { unemployment allowance, } \\
\text { housing benefits) }\end{array}$} & Yes & $46 \%$ & Yes & $47 \%$ \\
\hline & No & $42 \%$ & No & $47 \%$ \\
\hline & Missing & $12 \%$ & Missing & $5 \%$ \\
\hline \multirow[b]{2}{*}{ Disabilities } & Yes, I do & $35 \%$ & Yes, I do & $40 \%$ \\
\hline & $\begin{array}{l}\text { Yes, another } \\
\text { member of the } \\
\text { household }\end{array}$ & $14 \%$ & $\begin{array}{l}\text { Yes, another } \\
\text { member of the } \\
\text { household }\end{array}$ & $28 \%$ \\
\hline
\end{tabular}

* Note: According to the English Housing Survey for the social rented sector, the average age for the household reference person (HRP) was 52, with slightly more females (56\%) than males; $42 \%$ of HRPs were in employment and $28 \%$ were retired, $59 \%$ were in receipt of housing benefit, $17 \%$ of HRPs or their partner were registered disabled, and a further $49 \%$ reported a long-term illness or disability [19].

The majority of respondents were 45 years or older and female. Retired or in employment made up the two biggest categories, and nearly half reported being in receipt of welfare benefits, and considered themselves, or another member of their household, to have a disability. Although the aim of this research was not to study a representative sample of the population, Table 1 shows that the demographics are fairly representative of the overall social housing sector in England (see Table 1), with a slight overrepresentation of retired households and underrepresentation of employed households in the current sample. 


\subsubsection{Survey B}

In January 2017, all 88 homes that would participate in the field study to test the serious energy game received a home visit to record their energy meter readings. These 88 homes were drawn from the same sample of households as the 2772 households contacted for Survey A. Survey B, a self-report, paper-based survey, was sent to the 88 households, together with a letter informing about the purpose of the home visit and requesting the resident to complete the survey. If the residents had not completed the survey at the time of the visit, they were provided with another copy of the survey and a prepaid return envelope. Vouchers were used as an incentive to encourage responses, and two further reminder letters were send out in the weeks following this initial contact.

The survey included questions on respondents' interest in playing a serious energy game, as well as open- and closed-ended questions on their motivations for playing the game (see Appendix A for full items). In total, 78 of the households completed the survey ( $88.6 \%$ response rate); similar to Survey A, the number of valid cases for each analysis varies due to missing data and 'not applicable' responses. As can be seen in Table 1, the demographics of the Survey B sample were very similar to those for Survey A.

Finally, Surveys A and B also included five items measuring energy saving perceptions, specifically the following: energy saving attitudes (two items), perceived control over energy use in the home, social norms (i.e., whether friends and family say it is important to save energy), and financial worries about the energy bill (see Appendix A for full items).

\section{Results: Perceptions of a Serious Energy Game among Social Housing Residents}

\subsection{Which Characteristics Do Social Housing Residents Look for in a Serious Energy Game?}

A logical first step in designing a serious energy game for social housing residents would be to explore what residents are looking for in a game. When asked to think about a game that would help households save energy, which suggestions do the residents come up with that would make them want to play the game? This is what households were asked in Survey A; twenty-two percent $(n=120)$ of all respondents to Survey A provided an answer to this question. An exploratory thematic analysis of these answers revealed that the responses could be divided into two main groups, that is, suggestions for the game $(68 \%)$ or disinterest in energy saving games $(28 \%)$. The remaining responses $(4 \%)$ could not be categorised in either group or were unrelated to the question.

With regards to suggestions for the game, respondents often provided more than one suggestion. For example, one respondent noted that the game "would have to be easy to access and use, fun, colourful". Overall, several themes emerged across the responses. Most often included in the responses was a need for the game to be fun, enjoyable, and/or interesting (included in $21 \%$ of 82 responses). This was sometimes noted along with action as being particularly important to keep attention: "Interesting and challenging gameplay, my attention tends to stray when I'm bored of a game".

Secondly, respondents often noted that an energy saving game should be easy to use and quick to understand (included in $18 \%$ of 82 responses). For instance, one respondent noted that the game should be "easy for non game players", while another stated that it should have "very easy step-by-step instructions". Ease of use was often related to the need for the game to be suitable for different age groups (included in 16\% of 82 responses), as illustrated by the following quotes: "not complicated, appeals to a range of ages" and "constructive info for all ages".

Smaller categories of responses related to more specific suggestions regarding the content of the game. Most commonly mentioned was including rewards (in $12 \%$ of 82 responses), followed by including a challenge $(9 \%)$, including specific information on energy usage or costs $(6 \%)$, explaining ways to save energy or money (5\%), and including an option to play or share content with friends $(4 \%)$. In fact, some answers ( $11 \%$ of 82 responses) contained very specific game ideas, often related to games that respondents had played before or were familiar with: 
A cost budget that goes down. So would start with high amount of money and thus would reduce, while trying to fix and maintain household before going bust-Maybe like Monopoly—or Chance.

In summary, based on the comments from the respondents, a serious energy game needs to be, first and foremost, fun and enjoyable. At the same time, respondents suggest that the game should be easy to use, suitable for multiple age groups, and include elements from familiar, popular games. Interesting to note is that no large, common theme emerged from the analysis. The largest category (i.e., fun) was mentioned in $21 \%$ of the responses. A range of suggestions were proposed, reflecting a variety of opinions of what should be included in an energy saving game.

However, the remaining responses to the question (28\%) reflected an active disinterest in an energy saving game. Some respondents commented that they would rather receive simple energy saving information ( $6 \%$ out of 34 responses), as illustrated by these quotes:

Cannot think of any reason why I would want to do so. A simple process that tells me what each item is using/uses and the actual cost per hour, etc., would suffice.

I don't believe this is truly possible. I'd rather be given tips/hints to save real money on my bills. I don't want to play games about energy.

Others commented on other energy efficiency measures that they felt were needed and which should be prioritized ( $6 \%$ out of 34 responses):

Don't play games where energy is concerned. Need to insulate properties from externally. Then there would be far more energy saving and less maintenance on all of [social housing provider's] property, this being cost effective on both parties.

However, the majority of these comments related to a lack of interest in games in general or specifically on energy use, and the assumption that playing a game would not be feasible $(94 \%$ out of 34 responses). Respondents noted that they had "no time to waste", including one person who thought an energy saving game would be "a ridiculous idea, [ . . . I You are asking people to save energy by wasting energy (and time) on a game!" Other responses illustrate why respondents felt it difficult to imagine how playing an energy saving game would fit with their lifestyles:

As the only full-time worker in the family I hardly find the time to use the computer only where necessary. I do not have any game on the computer, too busy for that.

First of all I'd need to be able to afford to buy a computer, then pay a subscription to an internet provider then pay for lessons to learn how to use it. I can't imagine as a pensioner that I could ever afford this.

So, work pressures, busy lifestyles, and age might be factors that prevent social housing residents from engaging with a serious energy game. These responses reflect a potential negative stance towards a serious energy game. Specifically, the data here raises the question whether a serious gaming approach is appropriate in isolation for busy, time-pressured households and elderly residents. This question is further explored using data from Survey B where specific questions were asked about interest in a serious energy game and the underlying motivations explaining these perceptions.

\subsection{Which Factors Are Related to Interest in Playing a Serious Energy Game among Social Housing Residents?}

As may be recalled, Survey B was conducted among a subsample $(n=78)$ of social housing residents who would participate in a field study where the serious energy game would be tested. Respondents were told that they would receive a free tablet for participating in the project and were asked to what extent they would be interested in playing a game on their tablet about energy use and saving. They could give their response on a 4-point scale ranging from 1 (very interested) to 4 (not at all interested). The average response was $1.82(S D=0.68)$, so respondents were fairly interested in 
playing a serious energy game. Interest in a serious energy game was similar for male and female respondents, across age groups, for households with and without children under 18 years of age, and across respondents with different employment backgrounds (see Table 2).

Table 2. Differences in serious energy game interest depending on gender, age, presence of children in the household, and employment status.

\begin{tabular}{cc}
\hline Demographic Variable & Statistical Test * \\
\hline Gender & $U=673.50, p=0.583$ \\
Age & $X^{2}(\mathrm{df}=5)=2.29, p=0.808$ \\
Children under 18 years of age & $U=365.50, p=0.091$ \\
Employment status & $X^{2}(\mathrm{df}=5)=9.32, p=0.097$ \\
\hline
\end{tabular}

* Note: nonparametric tests were used to account for the difference in group sizes and non-normal distributions.

To examine whether interest in a serious energy game relates to broader energy saving perceptions, interest was correlated with energy saving attitudes, perceived control over energy use in the home, social norms, and financial worries about the energy bill (see Table 3). The results in Table 3 suggest that people expressed more interest in playing a serious energy game the more positive their attitudes towards energy saving were, and the more they reported having friends and family who feel the same. However, there was no association between worry about energy bills and feelings of control over energy use and interest in playing an energy saving game.

Table 3. Correlations between serious energy game interest and energy saving perceptions.

\begin{tabular}{|c|c|c|}
\hline Variable & Survey Item * & $\begin{array}{c}\text { Correlation with Serious Energy } \\
\text { Game Interest ** }\end{array}$ \\
\hline \multirow[t]{2}{*}{$\begin{array}{l}\text { Attitudes towards } \\
\text { energy saving }\end{array}$} & I often think about how I could save energy & $r=0.36, p=0.001$ \\
\hline & $\begin{array}{l}\text { I am prepared to save energy with the } \\
\text { right support }\end{array}$ & $r=0.43, p<0.001$ \\
\hline Perceived control & $\begin{array}{l}\text { I have control over how much energy is } \\
\text { consumed in my home }\end{array}$ & $r=0.07, p=0.529$ \\
\hline Social norms & $\begin{array}{l}\text { My friends and family say it's important to } \\
\text { save energy }\end{array}$ & $r=0.33, p=0.003$ \\
\hline Financial worries & I am worried about my energy bills & $r=0.11, p=0.340$ \\
\hline
\end{tabular}

Respondents were also asked more directly about their motivations for playing a serious energy game. After they rated their overall interest, they were asked to explain their rating in an open-ended question. Out of the 78 responses to the survey, 56 respondents provided an answer to this question. Respondents also rated the extent to which they agreed with four reasons why they might be interested in playing a game about energy use and saving, i.e., (1) it would make it fun to deal with energy use in my home; (2) it would help me learn what I can actually do to save energy; (3) it would help me to reduce my energy bills; and (4) it would encourage others in my home to think about how they use energy. There is overlap between the responses to these two aspects so they will be discussed together here.

The motivations were rated on a 5-point scale, ranging from 1 (strongly agree) to 5 (strongly disagree). On average, learning what to do to save energy $(M=1.88, S D=0.82)$ and helping to reduce energy bills $(M=1.90, S D=0.84)$ were rated as important reasons for interest in playing an energy game. This was followed by making it fun to deal with energy use $(M=2.05, S D=0.82)$, and encouraging others to think about energy use $(M=2.11, S D=0.98)$. Respondents agreed more strongly that they would be interested in the game if it would help them learn what to do to save energy, compared to whether it would make it fun to deal with energy use in the home (Wilcoxon 
Signed Ranks $Z=-2.27, p=0.023$ ). This is also reflected in the qualitative responses: in an exploratory thematic analysis, wanting to learn about energy use and how to save energy emerged as one of the main themes (mentioned in $25 \%$ of 56 responses). The responses showed that social housing residents were looking for specific information on how, when, and where to save energy:

\section{Hoping to educate myself and family to how the home uses energy and how to make changes to save energy.}

I would like to get to know when and where I can save energy in my home.

Having fun was only mentioned by a small proportion of the respondents ( $4 \%$ of 56 responses); for instance, one respondent noted a game would be "a fun way to find ways to save energy and money". This is seemingly in contrast to the results reported earlier from Survey A, where a large proportion of respondents noted that a game would have to be fun for them to be interested in playing it. This might reflect a difference between the two samples, but it could also reflect a difference between what householders would like to see in a serious energy game (reported in Survey A) and what householders expect to see in a serious energy game (reported in Survey B). That is, in Survey B, householders are asked to explain why they would (or would not) be interested in playing an existing game.

Furthermore, the ratings showed that respondents agreed more strongly that they would be interested in the game if it would help them reduce their energy bill, compared to whether it would encourage others to save energy (Wilcoxon Signed Ranks $Z=-2.06, p=0.040$ ). Again, this is also reflected in the qualitative data, where a common theme was wanting help to save energy and money (mentioned in $27 \%$ of 56 responses): "I am open to any help, advice, ideas to help me reduce my energy bills". With regards to encouraging others to save energy, a small category of responses ( $5 \%$ of 56 responses) related to playing the game with family or children, as noted by one respondent: "kids will enjoy playing too".

The qualitative responses also showed that some respondents did not have a specific reason or motivation to be interested in playing a serious energy game; they were simply curious and willing to try it out ( $11 \%$ of 56 responses). These respondents wanted to "see what it's all about", though some noted that it would depend on the design of the game: "would play it, it would then depend on the interest in the game as to if we would continue with it". However, others were less favourable towards playing a serious energy game, and expressed having no interest in playing a serious energy game $(16 \%$ of 56 responses). Furthermore, similar to earlier reported results from Survey A, some respondents noted that constraints due to age or disabilities or lack of computer literacy would prevent them from playing a serious energy game ( $9 \%$ of 56 responses), as noted by one participant: "partially sighted, unable to see games properly".

In summary, overall, respondents were fairly interested in playing a serious energy game. Exploring these findings further showed that this was especially the case for respondents already interested in energy saving and surrounded by energy saving social norms (i.e., those who had friends and family who think energy saving is important as well). Although earlier results showed that households wanted a serious energy game to be fun and enjoyable, wanting to have fun was not an important reason why respondents reported being interested in playing a serious energy game. Instead, being able to learn specific know-how on what to do to save energy at home seemed to be an important reason for householders' interest in a serious energy game. However, both surveys indicated that certain age groups or people with disabilities might have difficulties with a digital serious energy game. This is especially relevant in the context of social housing which tends to consist of an older segment of the population with a higher proportion of disabilities compared to the general population.

\subsection{What Is the Role of Access, Experience, and Confidence with Digital Media in the Potential Uptake of a} Serious Energy Game in the Social Housing Context?

As discussed at the start of Section 3.2. interest in a serious energy game was similar across different age groups. However, the qualitative responses do indicate some concern as to how (and if) 
elderly residents and residents with disabilities could engage with a serious energy game. How the uptake of a serious energy game in a social housing population could be influenced by these factors is further examined with data from Survey A on access, experience, and confidence with digital media.

First of all, respondents were asked whether they had regular access to the internet. The results from the survey showed that the majority of households had regular access (64\% out of 536); however, about a quarter of households did not have regular access, and were not interested in this $(22 \%$ out of 536). Smaller groups of respondents indicated that they had access to the internet elsewhere ( $2 \%$ out of 536), did not have regular access but would like to ( $9 \%$ out of 536), or did not provide an answer to the question ( $3 \%$ out of 536). Table 4 shows the relationship between internet access, age, welfare benefits (e.g., unemployment allowance, housing benefit), and reported disability. Respondents without regular internet access at home were more likely to be in receipt of welfare benefits and to consider themselves disabled. Also, on average, respondents who were not interested in having regular access to the internet were older compared to those who had regular internet access.

Table 4. Relationship between regular access to the internet and age, welfare benefits, and reported disability.

\begin{tabular}{ccccccc}
\hline \multicolumn{7}{c}{ Do You Have Regular Access to the Internet? } \\
\hline & $\begin{array}{c}\text { Yes, at } \\
\text { Home }\end{array}$ & $\begin{array}{c}\text { Yes, } \\
\text { Elsewhere }\end{array}$ & $\begin{array}{c}\text { No, but Would } \\
\text { Like to }\end{array}$ & $\begin{array}{c}\text { No, Not } \\
\text { Interested }\end{array}$ & $\begin{array}{c}\text { Statistical } \\
\text { Analysis * }\end{array}$ \\
\hline \multirow{2}{*}{ Age } & & $M=52$ & $M=55$ & $M=60$ & $M=73$ & $\chi^{2}(\mathrm{df}=3)=115.14$, \\
& & $S D=15.88$ & $S D=18.19$ & $S D=14.99$ & $S D=12.15$ & $p<0.001$ \\
\hline \multirow{2}{*}{$\begin{array}{c}\text { Welfare } \\
\text { benefits }\end{array}$} & Yes $(n=242)$ & $59 \%$ & $3 \%$ & $16 \%$ & $23 \%$ & $\chi^{2}(\mathrm{df}=3)=31.49$, \\
\cline { 2 - 7 } Disabled & No $(n=220)$ & $81 \%$ & $2 \%$ & $3 \%$ & $14 \%$ & $p<0.001$ \\
& Yes $(n=182)$ & $59 \%$ & $2 \%$ & $11 \%$ & $28 \%$ & $\chi^{2}(\mathrm{df}=3)=14.79$, \\
& No $(n=304)$ & $74 \%$ & $3 \%$ & $8 \%$ & $16 \%$ & $p=0.002$ \\
\hline
\end{tabular}

* Note: $M=$ Mean; $S D$ = Standard Deviation; nonparametric tests were used to account for the difference in group sizes and non-normal distributions.

Secondly, respondents were asked whether they, or other members of their household, play games on, for instance, computers, smartphones, tablets, or video game consoles. Out of the 536 respondents to the survey, just over half answered no to this question (52\%); the remainder answered yes $(41 \%)$ or did not provide an answer to this question ( $8 \%$ ). As was found with regards to internet access, the responses to this question also related to age, welfare benefits, and reported disability. The data in Table 5 shows that younger respondents who did not consider themselves to be disabled were more experienced with playing games. The proportion of game players was slightly higher among respondents who did not receive welfare benefits.

Finally, two questions were included in the survey to assess how confident respondents felt when using a computer and when using the internet. On a 5-point scale, ranging from strongly agree (1) to strongly disagree (5), the mean scores showed that on average respondents felt fairly confident when using a computer $(M=2.21, S D=1.30)$ and the internet $(M=2.15, S D=1.28)$. The older respondents were, the less confident they were about computer use $(r=0.36, p<0.001)$ and internet use $(r=0.42, p<0.001)$. Furthermore, respondents who received welfare benefits and considered themselves disabled felt less confident when using a computer and the internet, as shown in Table 6.

In this sample of social housing residents, the percentage of households with regular access to the internet was lower compared to the average percentage in the UK (i.e., 90\%, [59]). Moreover, there is a clear pattern wherein older, disabled residents who are in receipt of welfare benefits have reduced access to the internet, less experience with gaming, and lower confidence regarding using a computer and the internet. This is important data to consider when implementing a serious energy game in this population. Getting people engaged with a serious energy game might be limited by a lack of confidence and ability to interact with a serious energy game. 
Table 5. Relationship between game playing experience and age, welfare benefits, and reported disability.

\begin{tabular}{|c|c|c|c|c|}
\hline & & \multicolumn{2}{|c|}{$\begin{array}{l}\text { Do You or Any Other Members of Your Household Play Games? } \\
\text { (e.g., on Computers, Smartphones, Tablets, Video Games } \\
\text { Consoles, etc.) }\end{array}$} & \multirow[b]{2}{*}{ Statistical Analysis * } \\
\hline & & Yes & No & \\
\hline Age & & $\begin{array}{c}M=47 \\
S D=14.09\end{array}$ & $\begin{array}{c}M=64 \\
S D=14.79\end{array}$ & $\mathrm{U}=10,181.00 p<0.001$ \\
\hline Welfare benefits & $\begin{array}{l}\text { Yes }(n=231) \\
\text { No }(n=216)\end{array}$ & $\begin{array}{l}41 \% \\
53 \%\end{array}$ & $\begin{array}{l}59 \% \\
47 \%\end{array}$ & $\chi^{2}(\mathrm{df}=1)=7.06, p=0.008$ \\
\hline Disabled & $\begin{array}{l}\text { Yes }(n=176) \\
\text { No }(n=293)\end{array}$ & $\begin{array}{l}36 \% \\
51 \%\end{array}$ & $\begin{array}{l}64 \% \\
49 \%\end{array}$ & $\chi^{2}(\mathrm{df}=1)=9.75, p=0.002$ \\
\hline
\end{tabular}

* Note: $M$ = Mean; $S D$ = Standard Deviation; nonparametric tests were used to account for the difference in group sizes and non-normal distributions.

Table 6. Relationship between confidence with using a computer and the internet, and welfare benefits and reported disability.

\begin{tabular}{|c|c|c|c|}
\hline & & \multicolumn{2}{|c|}{ I Feel Confident Using * } \\
\hline & & $\begin{array}{c}\text { A Computer } \\
M(S D)\end{array}$ & $\begin{array}{c}\text { The Internet } \\
M(S D)\end{array}$ \\
\hline \multirow{3}{*}{ Welfare benefits } & Yes & $2.40(1.36)$ & $2.39(1.38)$ \\
\hline & No & $1.99(1.20)$ & $1.90(1.12)$ \\
\hline & Statistical analysis ** & $U=14,413.50, p=0.003$ & $U=12,931.00, p=0.001$ \\
\hline \multirow{3}{*}{ Disabled } & Yes, I do & $2.47(1.39)$ & $2.47(1.39)$ \\
\hline & No & $2.07(1.22)$ & $1.97(1.18)$ \\
\hline & Statistical analysis ** & $U=14,013.50, p=0.008$ & $U=12,420.50, p=0.001$ \\
\hline
\end{tabular}

* Note: $M=$ Mean; $S D$ = Standard Deviation; Response scale: 1 (strongly agree) to 5 (strongly disagree); ** Note: nonparametric tests were used to account for the difference in group sizes and non-normal distributions.

\section{Discussion}

Household energy use is a pressing concern among many residents in the social housing sector [21]. A key challenge faced by communicators looking to help residents manage their energy more efficiently is to determine means of making energy use more visible and tangible. Serious games offer a potential novel way of engaging householders with energy use and saving. These games have been successful in the health domain and other fields in guiding behaviour and breaking down complex goals into more manageable objectives [37]. With regards to energy conservation, serious games allow users to try out new behaviours in a safe environment and receive immediate feedback. Importantly, serious games are thought to offer the opportunity to change everyday habitual behaviours, such as day-to-day energy behaviours, in an enjoyable and engaging way [35]. However, there are relatively few studies on the use of serious games in the context of household energy use [51]. This paper responded to a need to examine the potential of serious games in a setting where residents may have, or perceive, limited agency as to what they can do to save energy. By studying perceptions among social housing residents at an early stage in a project where a serious energy game is developed, we aimed to explore whether serious energy games can overcome one of the major obstacles in communicating about energy conservation: getting householders interested and engaged.

Survey responses showed that our sample of social housing residents were fairly interested in playing a serious energy game. Overall, residents felt that a game should be fun and enjoyable and easy to use for all ages. Furthermore, residents were motivated to play the game if it would teach them specific information on how, when, and where to save energy in their home. So, residents were looking for actionable solutions that could help them reduce their energy bills. In terms of energy saving perceptions, having positive attitudes towards any saving and having friends and family who feel the same related to a stronger interest in a serious energy game.

However, from the survey responses it also became clear that a large proportion of social housing residents felt negative towards the prospect of using a game to learn about energy use and saving. 
There was an overall sense that residents already felt time-pressured and needed quick and simple advice; for these residents, a game was not seen as an appropriate way to gather information. There was also a perception that energy use is a serious topic-one that we should not play games about. This observation seems to go against the notion that people want 'playful' forms of information and feedback [15]. Additionally, the sample consisted of a relatively high proportion of elderly and/or disabled residents, which is not uncommon for the social housing sector. These residents in particular found it difficult to imagine how a serious energy game could be suitable for them. Further analysis showed that confidence in using the internet and computers tended to be low among these residents; additionally, they were less likely to have experience with gaming or regular access to the internet.

It should be noted that, although fairly representative of the social housing population in England, the sample of households in this study (especially for Survey B) was relatively small. In particular, there was a fair amount of missing data which may have led to an overrepresentation of residents with a strong opinion in favour of or against a game on energy use and saving. Also, respondents were asked to offer their opinion on a hypothetical game without being provided with an example. However, this helped us get an insight into the initial reactions that the residents had towards a game on energy use and saving, which was the topic of interest for the current research.

\section{Implications and Conclusions}

This case study shows that the uptake of a serious energy game among social housing residents could potentially be met with many challenges. Although some residents see potential in a serious game as offering a fun way to engage with energy use, the potential issues that emerged from the responses should not be underestimated. Moving forward, this case study provides two important questions that should be kept in mind when designing a serious energy game in this sector: firstly, how to deal with the negative opinions towards games on energy use; and secondly, how to make the game suitable for the large proportion of elderly and disabled residents living in social housing. Research has highlighted that effective serious energy games that can keep people's interest over time need to include personally relevant information, provide clear and actionable feedback, and at the same time be able to engage with a diverse group of people, allow them to make informed decisions, and take control of their energy use [51]. This is not an easy task, and in addition the current case study emphasizes the challenges of getting householders engaged with the game in the first place, and targeting hard-to-reach segments of the population. In part, the answer to these questions lies in the design of the game and some of these concerns might be addressed by carefully co-designing the game with the users. This can help to ensure that any concerns regarding the usefulness and suitability of the game are addressed, so the game fits with the needs of the residents. However, developing an effective strategy to co-design a serious energy game with users requires further research. In the current study, co-design workshops were organised by the games developer but residents were slow to sign up and numbers participating were very small. This could be due to the negative expectations as to what a game on energy use could offer, or simply due to the fact that these residents are a particularly time-pressured and hard-to-reach sample of the housing sector.

Different approaches may also be needed for different groups of residents. For example, parents tended to reply positively and saw the game as an opportunity to engage their children with energy use. At the same time, developing a material game (e.g., board/card games) alongside a digital game may help to engage elderly residents (also mentioned by [51]). With regards to elderly and/or disabled residents, our findings point towards a potential role for 'digital literacy' in the uptake of serious energy games. This term refers to the ability to read, understand, and assemble knowledge from digital and nondigital formats as well as to create, communicate, and evaluate digital information [60]. Previous research has shown that limited use of the internet among older adults can reduce their access to-increasingly common-web-based health interventions [61]. Similarly, low digital literacy may limit elderly residents from engaging effectively with a serious energy game. This is an important 
issue that needs to be kept in mind, especially when working with vulnerable communities such as social housing residents.

Overall, as a technological innovation, serious gaming could provide a novel, interactive tool for communicators to use in the effort to reduce energy demand and move the energy transition forward. However, social and behavioural insights suggest that implementing a digital serious energy game in isolation is unlikely to be sufficient to engage residents, and face-to-face meetings and events which build up a culture of energy awareness over some time may be necessary in order to enable the gaming tool to reach its potential. Social change processes are different from technical change processes in that respect and may need a more multipronged approach. This highlights the need for multidisciplinary approaches where social scientists, IT developers, engineers, and users work closely together to design effective solutions, while using a multifaceted approach presenting a serious energy game as part of a wider engagement strategy to reach as many householders as possible in order to transform serious gaming from a purely technological innovation to a social innovation as well.

Author Contributions: C.B., S.P., R.V.J., and A.F. conceived and designed the research and collected the data; C.B. analyzed the data; C.B. and R.H. wrote the original draft; all authors were involved in reviewing and editing the paper.

Funding: This project has received funding from the European Union's Horizon 2020 research and innovation programme under grant agreement No. 649673.

Acknowledgments: The research reported in this paper was undertaken as part of the EnerGAware project: Energy Game for Awareness of energy efficiency in social housing communities.

Conflicts of Interest: The authors declare no conflict of interest.

\section{Appendix A}

Table A1. Measures Included in the Surveys.

\begin{tabular}{|c|c|c|}
\hline & Item & Response Options \\
\hline \multicolumn{3}{|l|}{ Survey 1} \\
\hline \multirow{4}{*}{$\begin{array}{l}\text { Access, experience, and } \\
\text { confidence with digital media }\end{array}$} & Do you have regular access to the internet & $\begin{array}{l}\text { Yes at home; Yes elsewhere; No but I } \\
\text { would like to; No not interested }\end{array}$ \\
\hline & $\begin{array}{l}\text { Do you or any other members of your household } \\
\text { play games (e.g., on computers, smartphones, tablets, } \\
\text { video games consoles, etc.) }\end{array}$ & Yes; No \\
\hline & I feel confident using a computer & 1 (Strongly agree) to 5 (Strongly disagree) \\
\hline & I feel confident using the internet & 1 (Strongly agree) to 5 (Strongly disagree) \\
\hline Game interest & $\begin{array}{l}\text { Thinking about the design of a game to help } \\
\text { households save energy, what would it have to } \\
\text { include to make you want to play it }\end{array}$ & (Open question) \\
\hline \multicolumn{3}{|l|}{ Survey 2} \\
\hline \multirow{3}{*}{ Game interest and motivations } & $\begin{array}{l}\text { For participating in the EnerGAware project you will } \\
\text { receive a free tablet. To what extent would you be } \\
\text { interested in playing a game on your tablet about } \\
\text { energy use and saving? }\end{array}$ & $\begin{array}{l}\text { Very interested; Fairly interested; Not } \\
\text { very interested; Not at all interested }\end{array}$ \\
\hline & $\begin{array}{l}\text { Please explain your answer to the previous questions } \\
\text { in the box below }\end{array}$ & (Open question) \\
\hline & $\begin{array}{l}\text { I would be interested in playing a game about energy } \\
\text { use and saving on my tablet if: It would make it fun } \\
\text { to deal with the energy use in my home; It would } \\
\text { help me learn what I can actually do to save energy; } \\
\text { It would help me to reduce my energy bills; It would } \\
\text { encourage others in my home to think about how } \\
\text { they use energy }\end{array}$ & 1 (Strongly agree) to 5 (Strongly disagree) \\
\hline
\end{tabular}


Table A1. Cont.

\begin{tabular}{|c|c|c|}
\hline & Item & Response Options \\
\hline \multicolumn{3}{|l|}{ Included in both surveys } \\
\hline \multirow{4}{*}{ Energy saving perceptions } & $\begin{array}{l}\text { Attitudes towards energy saving ( } 2 \text { items): I often } \\
\text { think about how I could save energy; I am prepared } \\
\text { to save energy with the right support }\end{array}$ & 1 (Strongly agree) to 5 (Strongly disagree) \\
\hline & $\begin{array}{l}\text { Perceived control ( } 1 \text { item): I have control over how } \\
\text { much energy is consumed in my home }\end{array}$ & 1 (Strongly agree) to 5 (Strongly disagree) \\
\hline & $\begin{array}{l}\text { Social norms ( } 1 \text { item): My friends and family say it's } \\
\text { important to save energy }\end{array}$ & 1 (Strongly agree) to 5 (Strongly disagree) \\
\hline & $\begin{array}{l}\text { Financial worries ( } 1 \text { item): I am worried about my } \\
\text { energy bills }\end{array}$ & 1 (Strongly agree) to 5 (Strongly disagree) \\
\hline
\end{tabular}

\section{References}

1. Fischer, C. Feedback on household electricity consumption: A tool for saving energy? Energy Effic. 2008, 1, 79-104. [CrossRef]

2. Burgess, J.; Nye, M. Re-materialising Energy Use through Transparent Monitoring Systems. Energy Policy 2008, 36, 4454-4459. [CrossRef]

3. Attari, S.Z.; DeKay, M.L.; Davidson, C.I.; Bruine de Bruin, W. Public Perceptions of Energy Consumption and Savings. Proc. Natl. Acad. Sci. USA 2010, 107, 16054-16059. [CrossRef] [PubMed]

4. Boomsma, C.; Goodhew, J.; Goodhew, S.; Pahl, S. Improving the Visibility of Energy Use in Home Heating in England: Thermal Images and the Role of Visual Tailoring. Energy Res. Soc. Sci. 2016, 14, 111-121. [CrossRef]

5. Pahl, S.; Goodhew, J.; Boomsma, C.; Sheppard, S.R. The role of energy visualization in addressing energy use: Insights from the eViz project. Front. Psychol. 2016, 7, 92. [CrossRef] [PubMed]

6. Frederick, S.; Loewenstein, G.; O'Donoghue, T. Time Discounting and Time Preference: A Critical Review. J. Econ. Lit. 2002, 40, 350-401. [CrossRef]

7. Abrahamse, W.; Steg, L.; Vlek, C.; Rothengatter, T. A Review of Intervention Studies aimed at Household Energy Conservation. J. Environ. Psychol. 2005, 25, 273-291. [CrossRef]

8. Faruqui, A.; Sergici, S.; Sharif, A. The Impact of Informational Feedback on Energy Consumption—A Survey of the Experimental Evidence. Energy 2010, 35, 1598-1608. [CrossRef]

9. Birrell, S.A.; Young, M.S. The Impact of Smart Driving Aids on Driving Performance and Driver Distraction. Transp. Res. Part F Traffic Psychol. Behav. 2011, 14, 484-493. [CrossRef]

10. Schultz, P.W.; Estrada, M.; Schmitt, J.; Sokoloski, R.; Silva-Send, N. Using in-home displays to provide smart meter feedback about household electricity consumption: A randomized control trial comparing kilowatts, cost, and social norms. Energy 2015, 90, 351-358. [CrossRef]

11. Buchanan, K.; Russo, R.; Anderson, B. The question of energy reduction: The problem(s) with feedback. Energy Policy 2015, 77, 89-96. [CrossRef]

12. Hargreaves, T. The Visible Energy Trial: Insights from Qualitative Interviews. Working Paper 141. Tyndall Centre for Climate Change Research, 2010. Available online: http://www.tyndall.ac.uk/ publications/tyndall-working-paper/2010/visible-energy-trial-insights-qualitative-interviews (accessed on 26 February 2018).

13. Van Dam, S.S.; Bakker, C.A.; Van Hal, J.D.M. Home energy monitors: Impact over the medium-term. Build. Res. Inf. 2010, 38, 458-469. [CrossRef]

14. Pierce, J.; Odom, W.; Blevis, E. Energy aware dwelling: A critical survey of interaction design for eco-visualizations. In Proceedings of the 20th Australasian Conference on Computer-Human Interaction: Designing for Habitus and Habitat, Cairns, Australia, 8-12 December 2008. [CrossRef]

15. Lucero, A.; Karapanos, E.; Arrasvuori, J.; Korhonen, H. Playful or Gameful? Creating Delightful User Experiences. Interactions 2014, 21, 34-39. [CrossRef]

16. Langevin, J.; Gurian, P.L.; Wen, J. Reducing energy consumption in low income public housing: Interviewing residents about energy behaviors. Appl. Energy 2013, 102, 1358-1370. [CrossRef]

17. Pivo, G. Unequal access to energy efficiency in US multifamily rental housing: Opportunities to improve. Build. Res. Inf. 2014, 42, 551-573. [CrossRef] 
18. Winter Wellbeing, Corwall Council. Available online: http://www.cornwall.gov.uk/winterwellbeing (accessed on 26 February 2018).

19. Department for Communities and Local Environment. English Housing Survey: Social Rented Sector 2015-16; Department for Communities and Local Environment: London, UK, 2017; ISBN 978-1-4098-5085-4. Available online: https:/ / www.gov.uk/government/statistics/english-housing-survey-2015-to-2016-social-rentedsector (accessed on 26 February 2018).

20. Tunstall, R.; Bevan, M.; Bradshaw, J.; Croucher, K.; Duffy, S.; Hunter, C.; Jones, A.; Rugg, J.; Wallace, A.; Wilcox, S. The Links between Housing and Poverty: An Evidence Review; Joseph Rowntree Foundation: York, UK, 2013; ISBN 978-1-85935-975-4. Available online: https:/ / www.jrf.org.uk/report/links-between-housingand-poverty (accessed on 26 February 2018).

21. Pittini, A.; Ghekiere, L.; Dijol, J.; Kiss, I. The State of Housing in the EU 2015: A Housing Europe Review; Housing Europe: Brussels, Belgium, 2015. Available online: http:/ /www.housingeurope.eu/resource-468/the-stateof-housing-in-the-eu-2015 (accessed on 26 February 2018).

22. Antanasiu, B.; Kontonasiou, E.; Mariottini, F. Alleviating Fuel Poverty in the EU: Investing in Home Renovation, a Sustainable and Inclusive Solution; Buildings Performance Institute Europe (BPIE): Brussels, Belgium, 2014. Available online: http:/ / bpie.eu/wp-content/uploads/2015/10/Alleviating-fuel-poverty.pdf (accessed on 9 May 2018).

23. Evans, J.; Hyndman, S.; Stewart-Brown, S.; Smith, D.; Petersen, S. An epidemiological study of the relative importance of damp housing in relation to adult health. J. Epidemiol. Community Health 2000, 54, 677-686. [CrossRef] [PubMed]

24. Liddell, C.; Morris, C. Fuel poverty and human health: A review of recent evidence. Energy Policy 2010, 38, 2987-2997. [CrossRef]

25. Maidment, C.D.; Jones, C.R.; Webb, T.L.; Hathway, E.A.; Gilbertson, J.M. The impact of household energy efficiency measures on health: A meta-analysis. Energy Policy 2014, 65, 583-593. [CrossRef]

26. Hamilton, I.G.; Summerfield, A.J.; Shipworth, D.; Steadman, J.P.; Oreszczyn, T.; Lowe, R.J. Energy efficiency uptake and energy savings in English houses: A cohort study. Energy Build. 2016, 118, 259-276. [CrossRef]

27. Hamilton, I.G.; Steadman, J.P.; Bruhns, H.; Summerfield, A.J.; Lowe, R.J. Energy efficiency in the British housing stock: Energy demand and the Homes Energy Efficiency Database. Energy Policy 2013, 60, 462-480. [CrossRef]

28. Hong, S.H.; Gilbertson, J.; Oreszczyn, T.; Green, G.; Ridley, I. A field study of thermal comfort in low-income dwellings in England before and after energy efficient refurbishment. Build. Environ. 2009, 44, 1228-1236. [CrossRef]

29. Lopes, M.A.R.; Antunes, C.H.; Martins, N. Energy behaviours as promoters of energy efficiency: A 21st century review. Renew. Sustain. Energy Rev. 2012, 16, 4095-4104. [CrossRef]

30. Fogg, B. Persuasive Technology: Using Computers to Change what We Think and Do; Morgan Kaufmann Publishers: London, UK, 2003.

31. Ritterfeld, U.; Cody, M.; Vorderer, P. Serious Games: Mechanisms and Effects; Routledge: New York, NY, USA, 2010.

32. Waltz, S.P.; Deterding, S. An Introduction to The Gameful World. In The Gameful World: Approaches, Issues, Applications; Waltz, S.P., Deterding, S., Eds.; The MIT Press: Cambridge, MA, USA, 2015; pp. 1-14.

33. Mohsenian-Rad, A.H.; Wong, V.W.; Jatskevich, J.; Schober, R.; Leon-Garcia, A. Autonomous demand-side management based on game-theoretic energy consumption scheduling for the future smart grid. IEEE Trans. Smart Grid 2010, 1, 320-331. [CrossRef]

34. Hamari, J.; Koivisto, J.; Sarsa, H. Does Gamification Work? A Literature Review of Empirical Studies on Gamification. In Proceedings of the 47th Hawaii International Conference on System Science, Waikoloa, HI, USA, 6-9 January 2014.

35. Thaler, R.H.; Sunstein, C.R. Nudge: Improving Decisions about Health, Wealth, and Happiness; Yale University Press: New Haven, CT, USA; London, UK, 2008.

36. Lu, A.S.; Kharrazi, H. A State-of-the-Art Systematic Content Analysis of Games for Health. Games Health J. 2018, 7, 1-15. [CrossRef] [PubMed]

37. McGonigal, J. Reality Is Broken: Why Games Make Us Better and How They Can Change the World; Penguin: New York, NY, USA, 2011. 
38. DeSmet, A.; Van Ryckeghemb, D.; Compernolle, S.; Baranowski, T.; Thompson, D.; Crombez, G.; Poels, K.; Van Lippevelde, W.; Bastiaensens, S.; Van Cleemput, K.; et al. A Meta-analysis of Serious Digital Games for Healthy Lifestyle Promotion. Prev. Med. 2014, 69, 95-107. [CrossRef] [PubMed]

39. Ajzen, I. The Theory of Planned Behaviour. Organ. Behav. Hum. Decis. Process. 1991, 50, 179-211. [CrossRef]

40. Ölander, F.; Thøgersen, J. Informing versus Nudging in Environmental Policy. J. Consum. Policy 2014, 37, 341-356. [CrossRef]

41. Lerner, J.S.; Small, D.A.; Loewenstein, G. Heart Strings and Purse Strings: Effects of Emotions on Economic Transactions. Psychol. Sci. 2004, 15, 337-341. [CrossRef] [PubMed]

42. Munson, S.A.; Poole, E.; Perry, D.B.; Peyton, T. Gamification and Health. In The Gameful World: Approaches, Issues, Applications; Waltz, S.P., Deterding, S., Eds.; The MIT Press: Cambridge, MA, USA, 2015; pp. 597-624.

43. State of Green Business Report 2012. Available online: https:/ /www.greenbiz.com/research/report/2012/ 01/state-green-business-report-2012 (accessed on 28 February 2018).

44. Goldstein, N.; Cialdini, R.; Griskevicius, V. A Room with a Viewpoint: Using Social Norms to Motivate Environmental Conservation in Hotels. J. Consum. Res. 2008, 35, 472-482. [CrossRef]

45. Locke, E.A.; Latham, G.P. Building a Practically Useful Theory of Goal Setting and Task Motivation. Am. Psychol. 2002, 57, 705-717. [CrossRef] [PubMed]

46. Bolderdijk, J.W.; Steg, L.; Geller, E.S.; Lehman, P.K.; Postmes, T. Comparing the Effectiveness of Monetary versus Moral motives in Environmental Campaigning. Nat. Clim. Chang. 2012, 3, 413-416. [CrossRef]

47. Hafner, R.J.; Elmes, D.; Read, D. Exploring the Role of Messenger Effects and Feedback Frames in Promoting Uptake of Energy-Efficient Technologies. Curr. Psychol. 2017, 1-12. [CrossRef]

48. McKenzie-Mohr, D.; Smith, W. Fostering Sustainable Behaviour: An Introduction to Community-Based Social Marketing; New Society Publishers: Gabriola Island, BC, Canada, 1999.

49. Froehlich, J. Gamifying Green. In The Gameful World: Approaches, Issues, Applications; Waltz, S.P., Deterding, S., Eds.; The MIT Press: Cambridge, MA, USA, 2015; pp. 563-596.

50. Hedin, B.; Lundström, A.; Westlund, M.; Markström, E. The Energy Piggy Bank-A Serious Game for Energy Conservation. In Proceedings of the Fifth IFIP Conference on Sustainable Internet and ICT for Sustainability, Funchal, Portugal, 6-7 December 2017.

51. Wood, G.; van der Horst, D.; Day, R.; Bakaoukas, A.G.; Petridis, P.; Liu, S.; Jalil, L.; Gaterell, M.; Smithson, E.; Barnham, J.; et al. Serious Games for Energy Social Science Research. Technol. Anal. Strateg. Manag. 2014, 10, 1212-1227. [CrossRef]

52. Fijnheer, J.D.; van Oostendorp, H. Steps to Design a Household Energy Game. In Proceedings of the 4th International Conference on Games and Learning Alliance, Rome, Italy, 9-11 December 2015; pp. 12-22.

53. Gamberini, L.; Jacucci, G.; Spagnolli, A.; Corradi, N.; Zamboni, L.; Perotti, M.; Cadenazzi, C.; Mandressi, S.; Tusa, G.; Björkskog, C.; et al. Saving is Fun: Designing a Persuasive Game for Power Conservation. In Proceedings of the 8th International Conference on Advances in Computer Entertainment Technology, Lisbon, Portugal, 8-11 November 2011.

54. Kimura, H.; Nakajima, T. Designing Persuasive Applications to Motivate Sustainable Behavior in Collectivist Cultures. PsychNol. J. 2011, 9, 7-28.

55. Bang, M.; Svahn, M.; Gustafsson, A. Persuasive Design of a Mobile Energy Conservation Game with Direct Feedback and Social Cues. In Proceedings of the 2009 DiGRA International Conference Breaking New Ground: Innovation in Games, Play, Practice and Theory, London, UK, 1-4 September 2009.

56. Orland, B.; Ram, N.; Lang, D.; Houser, K.; Kling, N.; Coccia, M. Saving Energy in an Office Environment: A Serious Game Intervention. Energy Build. 2014, 74, 43-52. [CrossRef]

57. Reeves, B.; Cummings, J.; Scarborough, J.; Yeykelis, L. Increasing Energy Efficiency with Entertainment Media: An Experimental and Field Test of the Influence of a Social Game on Performance of Energy Behaviors. Environ. Behav. 2015, 47, 102-115. [CrossRef]

58. Cowley, B.; Bateman, C. Green My Place: Evaluation of a Serious Social Online Game Designed to Promote Energy Efficient Behaviour Change. Int. J. Serious Games 2017, 4, 71-90. [CrossRef]

59. Office for National Statistics. Internet Access-Households and Individuals: 2017; Office for National Statistics: London, UK, 2017. Available online: https://www.ons.gov.uk/ peoplepopulationandcommunity/householdcharacteristics/homeinternetandsocialmediausage/ bulletins/internetaccesshouseholdsandindividuals/2017 (accessed on 19 February 2018). 
60. Lankshear, C.; Knobel, M. Digital Literacies: Concepts, Policies and Practices; Peter Lang Publishing: New York, NY, USA, 2008.

61. Levy, H.; Janke, A.T.; Langa, K.M. Health literacy and the digital divide among older Americans. J. Gen. Intern. Med. 2015, 30, 284-289. [CrossRef] [PubMed] 